\title{
Quality of Work Life of Women Employee Problems in Banking Sector: A Study in Warangal District, Telangana
}

\author{
M. Aravinda ${ }^{1}$, N. Ratna Kishore ${ }^{2}$ \\ ${ }^{1}$ Department of MBA, AN University, Guntur, India \\ ${ }^{2}$ Department of MBA, AN University, India
}

\begin{abstract}
Indian Banking Industry which is more than a century, passed through many phases in the last 100 years like social control, nationalization, liberalization, privatization, globalization and finally computerization. To keep the pace with the competitiveness derived from the above changes the banking industry, which is the area of concern being manpower intensive, must consider the role of human resource as the most significant key to enhance the profitability, efficiency and overall organizational effectiveness. Women working and earning something is a part of a modern phenomenon, but even now a day's majority of the women have been challenged by inequality in the workforce. A women worker obviously plays a double role, the traditional feminine role of a house wife or mother or daughter and that of a worker. With the multiplicity of roles her behaviour becomes complex in terms of expected and actual conduct, and she faces a lot of confusion with regard to her role and status. The two roles might sometimes lead to a conflict, which is reflected in many ways in her life.
\end{abstract}

Keywords-Globalization, Indian banking, Women Working, House wife.

\section{INTRODUCTION}

India is the second largest populated country in the world and so is its female population. According to 2011 census, the female population of India is 586.5 million (48 per cent) of the total population (1210193422). Women constitute a significant part of the work force of India but they lag behind men in terms of level and quality of employment. The census of India, 2011 has registered 26 per cent of female population as workers; 127.22 million, in absolute terms out of a total female population of 586.5 million. The majority of women workers are employed in rural areas. Amongst rural women workers, 66 per cent are employed in agriculture as labourers and cultivators. Amongst the women workers in the urban areas, 80 per cent are employed in unorganized sectors like household industries, petty trades and services and building construction.
Although more women seek work, a vast majority of them get only poorly paid jobs in the informal sector, without any job security or social security. This is because of the increasing unemployment and under employment among the male members of the family and the increasing cost of living as a result of the neo liberal economic policies.

Globalisation has contributed in bringing about vast changes in the lives of women who have been able to avail the opportunities, which have opened up in various sectors of development. Economic globalisation has opened up tremendous opportunities for women and girls to have greater access to productive resources such as human and physical capital access to formal employment and geographical mobility. Prospects of higher and quality education have become feasible for those women who can afford them, economically and socially. Employment in technological and other advanced sector, having global bearing, have been opened up for suitably qualified women. With changing attitude towards women, especially in the urban areas, women enjoy more egalitarian set of gender relationship.

Augmentation of women's movements through exposures at the international level will help to bring about major changes in the economic, social and political lives of women contributing to the creation of new associations of women and the strengthening of their networks to offer mutual support and resources. Positive approach to economic and cultural migration will facilitate women to be exposed to better prospects at the international level. Reduction in gender inequalities will have positive effect on women's empowerment in the socio-economic context.

India's young, ambitious women are no longer content with teaching toddlers or living the cliché of office receptionists. Women today are flocking to vocational training institutes, journalism schools, modeling courses, even air hostess academics that have mushroomed in the wake of never - before employability that is sweeping the country. 
Attitudinal changes towards women's role in the family due to good education, benefits of family planning and health care, child care and good job opportunities will surely help in the development of more confident and healthy women. In many cases, globalization has come as platform for female empowerment as an instrument through which women have the possibility to better their own living conditions and that of their children. Globalisation has also encouraged "transnational mothering" as women leave for better paying jobs in foreign countries and send home money to someone who cares for their children.

In several countries in the region, new Information and Communication Technology (ICT) have improved the access to women to micro credit, employment opportunities and information in general. Because of this gradual empowerment, they have become less subject to discrimination of caste, colour, religion and oppressive work environment.

Thus, globalization has given women a scope to carve new roles to build new positive self-identities outside the domestic chores, Moreover, as members of various socioeconomic movements they find a way to cope with roleparadox $^{1}$.

\section{ROLE OF WOMEN IN FAMILY AND SOCIETY}

In the past, man was the hunter and he provided the requirements of the family. The women maintained the house and reared children. She was compelled to seek man's protection for her survival. This subordinate and dependent role of women became entrenched in the culture of the human race even after the advent of civilization. Man continues to have a dominant role and controls all the resources required to maintain the family. This dominance of men compelled women to get attached legally and emotionally to be as wives and mothers, mostly for the sake of survival.

Psychologically, the continuing male power structure stood in the way of women building on their own resources. It was considered unnatural for a woman to aspire for her independent existence. Women's compulsive role as wives and mothers severely inhibited their capacity to compete with men in resource generation and they were compelled to accept their roles as adjuncts to men. A great virtue was made of women being loyal and devoted wives and mothers.

\footnotetext{
${ }^{1}$ Radhika Yadav (2008), 'Women at work- In the era of globalization', Women's Link Vol. 14.No.4. Oct. - Dec. 2008 Published by Social Action Trust.,10 Institutional Area Lodi Road, New Delhi - 110003.
}

The male-dominated culture has resulted in women having almost no in their say in decision-making, either at home or in the society. Even now their participation seems to be negligible. Not long ago, women were denied of equal opportunity with men and this stood in the way of their development. Even higher education was denied to girls, because the emphasis was on their marriage and not on their professional career. Besides, the laws for emancipation of women were drafted and enacted only by men.

Women's participation is important for their own personal advancement and improvement of status in society. Women should join the labour force of the country on an equal footing with men and get integrated into the system. The beginning of the present century has witnessed an ever-increasing awakening among women. The movements for their emancipation have become a reality. The increasing needs of the family and a spiral rise in the cost of living have made men realise that opportunities have to be identified where women can play equally productive and responsible roles. Women, therefore, have been allowed to cross the barricades as active participants in social well being. Opportunities to women are in abundance now. Women have accepted the challenges boldly and have completely disproved all the myths about their being inferior to men.

Today, women enjoy privileged positions and their performance is ranked as not less than that of men. In spite of the increase in women's employment, their say in decision-making at home and outside is still insignificant. There has been a marked increase in women's employment in the financial sector since the 1950's, in both public sector banks and private foreign controlled banks. The increase has been marked in metropolitan cities. Women officers in banks are a recent phenomenon. This has become more significant because of direct recruitment and promotions ${ }^{2}$.

\section{Level of Education of Women in Banking Sector}

Indian women's are lack of access to higher education and it effectively excluded them from the well-paid and high status occupations. In this connection, there is need to study the level of education of women employees working in banks in the study area and to study the women level of education, the researcher categorized into three i.e. below graduation, graduation and above graduation. The relevant data collected and presented in Table -1.1 .

\footnotetext{
2 Kanchere, U.(1991), 'Bank Officers' Trade Unions and Women officers', in Chetana Kalbagh (ed.), Women and development, Vol.1, New Delhi. PP-35-36.
} 


\section{TABLES}

Table.1.1:Level of Education of Working Women

\begin{tabular}{|c|c|c|}
\hline $\begin{array}{c}\text { Level of } \\
\text { Education }\end{array}$ & Respondents & $\mathbf{\%}$ \\
\hline Below Graduation & 11 & 5 \\
\hline Graduation & 123 & 53 \\
\hline Above Graduation & 100 & 42 \\
\hline Total & $\mathbf{2 3 4}$ & $\mathbf{1 0 0}$ \\
\hline
\end{tabular}

Source: Primary data.

Above data indicates that the $53 \%$ of the women employees are graduates, $42 \%$ are above graduates and only $11 \%$ are below graduation. It is observed from the above analysis, that the majority of the women employees are graduates in the study area. Therefore, it can be concluded that the majority of the women are still lack of access to higher education in most of the countries and especially Indian women being denied entry to university.

\section{Designation-Wise Distribution of Working Women}

The women job-seekers find jobs in banks more attractive and more suitable to their nature. Now-a-days, large numbers of women's are occupying various positions in all cadres in banks. In this connection, there is need to study the designation of the women employees in banks and the relevant data collected and presented in Table 5.02 .

Table .1.02: Designation-Wise Distribution of Working

Women

\begin{tabular}{|c|c|c|}
\hline Designation & Respondents & \% \\
\hline Manager & 51 & 22 \\
\hline Officer & 95 & 41 \\
\hline Clerk & 88 & 37 \\
\hline Total & $\mathbf{2 3 4}$ & $\mathbf{1 0 0}$ \\
\hline
\end{tabular}

Source: Primary data.

Above data indicates that the $41 \%$ of the women employees are occupied officer position in banks in the study area, $37 \%$ are clerk and $22 \%$ are managers. It can be observed that the majority of the women employees are occupied officers and clerk designations than the managers. Therefore, it can be concluded that the man employees are again dominating in the promotions because women employees in banks miss promotion out of the fear of causing dislocation in the family though they have fully qualified themselves and other officer cadre exams conducted by the respective banks.

\section{Level of Income of Women Employees}

The women's are seeking jobs to supplement their family income and to gain economic independence in society. In this backdrop, there is need to study the income level of women employees in banking sector in the study area and the relevant data collected and tabulated in Table -5.03 .
Table.1.03: Income Level of Women Employees

\begin{tabular}{|c|c|c|}
\hline $\begin{array}{c}\text { Income Level (per } \\
\text { month) }\end{array}$ & Respondents & \% \\
\hline Below`25000 & 14 & 6 \\
\hline$` 25001$ to `35000 & 48 & 20 \\
\hline$` 36000$ to 45000 & 108 & 46 \\
\hline Above`46000 & 64 & 27 \\
\hline Total & $\mathbf{2 3 4}$ & $\mathbf{1 0 0}$ \\
\hline
\end{tabular}

Source: Primary data.

Above data revels that the $46 \%$ of the women employees earn between ' 36000 to ` 45000 per month, $27 \%$ are above `46000, $20 \%$ are between `25001 to ` 35000 and only $6 \%$ are below ' 25000 . It can be observed from the above analysis that the majority of the women employees are earn between the` 36000 to `45000 per month.

\section{Level of Experience of Women Employees}

The phenomenal growth of Indian banking sector has created massive employment opportunities for the educated unemployed youth of nation. It will give more comfort and convent place to working women. In this connection, there is need to study the level of experience of women employees in banking sector in the study area. The relevant data collected and tabulated in Table -5.04.

Table.1.04: Level of Experience of Women Employees

\begin{tabular}{|c|c|c|}
\hline $\begin{array}{c}\text { Experience (in } \\
\text { years) }\end{array}$ & Respondents & \% \\
\hline Less than 5 years & 29 & 12 \\
\hline 6 to 15 years & 39 & 17 \\
\hline 16 to 25 years & 96 & 41 \\
\hline Above 26 years & 70 & 30 \\
\hline Total & $\mathbf{2 3 4}$ & $\mathbf{1 0 0}$ \\
\hline
\end{tabular}

Source: Primary data.

Above data shows that the $41 \%$ of the women employees have between 16 to 25 years of experience in banks, $30 \%$ are above 26 years, $17 \%$ are between 6 to 15 years and $12 \%$ are having the less than 5 years of experience. Therefore, it can be concluded that the majority of the women employees are having above 15 years of experience in banks.

\section{Problems faced by the Women in Banks}

In the present scenario the work and family domains influence each other generally and it is a mix of work with family as much as family with the work. Especially, Women employees having more pressure about this and they involvement, demands and accomplishments in the employment and family domains are mutually interdependent. In this background, there is need to study what kind of problems faced by the women at work place. Here, the researcher identified major problems and collected their opinion towards the problems faced by 
women in banks. The relevant data collected and tabulated in Table -1.05 .

Table.1.05: Problems faced by Women Employees in

\begin{tabular}{|c|c|c|c|c|}
\hline \multicolumn{5}{|c|}{ Banks } \\
\hline $\begin{array}{l}\text { S. } \\
\text { No. }\end{array}$ & Factors & $\begin{array}{l}\text { Weighed } \\
\text { Score }\end{array}$ & $\begin{array}{c}\text { Weighed } \\
\text { Average } \\
\text { Score }\end{array}$ & Rank \\
\hline 1 & $\begin{array}{l}\text { Physical strain } \\
\text { necessitating } \\
\text { longer hours of } \\
\text { stay in the bank }\end{array}$ & 947 & 189.4 & 1 \\
\hline 2 & $\begin{array}{l}\text { Working } \\
\text { environment are } \\
\text { often male } \\
\text { dominated }\end{array}$ & 662 & 132.4 & 5 \\
\hline 3 & $\begin{array}{l}\text { Taking care of } \\
\text { family }\end{array}$ & 788 & 157.6 & 2 \\
\hline 4 & $\begin{array}{l}\text { Fear of transfer } \\
\text { which disturbs } \\
\text { family life and } \\
\text { domestic peace }\end{array}$ & 778 & 155.6 & 3 \\
\hline 5 & $\begin{array}{l}\text { Work and family } \\
\text { conflict }\end{array}$ & 773 & 154.6 & 4 \\
\hline
\end{tabular}

Source: Primary data.

Above data indicates that the various factors hindering women employee problems in banking sector. A greater ranking method has been applied to find out the major problems faced by women employees. The women employees are given $1^{\text {st }}$ rank to physical strain necessitating longer hours of stay in the bank, taking care family is occupied $2^{\text {nd }}$ rank, fear of transfer which disturbs family life and domestic peace is occupied $3^{\text {rd }}$ rank. The work and family conflict and working environment are often male dominated is occupied $4^{\text {th }}$ and $5^{\text {th }}$ rank respectively. Therefore, it can be concluded that the majority of the women employees having the problem of physical strain necessitating longer hours of stay in the bank, taking care of family and fear of transfer which disturbs family life and domestic peace.

\section{Opinion towards Women Role in Family}

Most of the Indian women's are joining baking sector and making their mark. The banking sector has provided new areas of opportunity for women and nationalization has been a key factor in countering some aspects of gender discrimination. In this backdrop, there is need to study the role of women for family or how much of time they are giving to the family. To study the role of women for family Likert five points scale was used i.e. SA Strongly Agree, $\quad$ A - Agree, N- Neither nor, DA - Disagree and SDA - Strongly Disagree. The relevant data collected and tabulated in table - 5.06.

Table.1.06: Opinion towards Role of Women in Family

\begin{tabular}{|c|l|c|c|c|c|c|}
\hline $\begin{array}{l}\text { S. } \\
\text { No. }\end{array}$ & \multicolumn{1}{|c|}{$\begin{array}{c}\text { Family } \\
\text { Factors }\end{array}$} & SA & A & N & DA & SDA \\
\hline 1 & $\begin{array}{l}\text { Taking care } \\
\text { of children's }\end{array}$ & $\begin{array}{c}85 \\
(36 \%)\end{array}$ & $\begin{array}{c}90 \\
(38 \%)\end{array}$ & $\begin{array}{c}14 \\
(06 \%)\end{array}$ & $\begin{array}{c}26 \\
(11 \%)\end{array}$ & $\begin{array}{c}19 \\
(08 \%)\end{array}$ \\
\hline 2 & $\begin{array}{l}\text { Taking care } \\
\text { of parents }\end{array}$ & $\begin{array}{c}34 \\
(15 \%)\end{array}$ & $\begin{array}{c}51 \\
(22 \%)\end{array}$ & $\begin{array}{c}31 \\
(13 \%)\end{array}$ & $\begin{array}{c}56 \\
(24 \%)\end{array}$ & $\begin{array}{c}62 \\
(26 \%)\end{array}$ \\
\hline 3 & $\begin{array}{l}\text { Maintaining } \\
\text { family } \\
\text { relations }\end{array}$ & $\begin{array}{c}44 \\
(19 \%)\end{array}$ & $\begin{array}{c}52 \\
(22 \%)\end{array}$ & $\begin{array}{c}27 \\
(12 \%)\end{array}$ & $\begin{array}{c}53 \\
(23 \%)\end{array}$ & $\begin{array}{c}58 \\
(25 \%)\end{array}$ \\
\hline 4 & $\begin{array}{l}\text { Managing } \\
\text { the Social }\end{array}$ & $\begin{array}{l}44 \\
(19 \%)\end{array}$ & $\begin{array}{c}58 \\
(25 \%)\end{array}$ & $\begin{array}{c}27 \\
(12 \%)\end{array}$ & $\begin{array}{c}48 \\
(21 \%)\end{array}$ & $\begin{array}{c}57 \\
(24 \%)\end{array}$ \\
\hline 5 & $\begin{array}{l}\text { Life } \\
\text { Participating } \\
\text { in family } \\
\text { discussions }\end{array}$ & $\begin{array}{c}46 \\
(20 \%)\end{array}$ & $\begin{array}{c}56 \\
(24 \%)\end{array}$ & $\begin{array}{c}24 \\
(10 \%)\end{array}$ & $\begin{array}{c}52 \\
(22 \%)\end{array}$ & $\begin{array}{c}56 \\
(24 \%)\end{array}$ \\
\hline
\end{tabular}

Source: Primary data.

Above data indicates that the $38 \%$ of the women employees are agree with the taking care of children, $36 \%$ are strongly agree and only $08 \%$ are strongly disagree. With regard to taking care of family, $22 \%$ of the women employees are agree, $15 \%$ are strongly agree and $26 \%$ are strongly disagree. Around $22 \%$ of the women employees are agree with the maintaining family relations, $19 \%$ are strongly agree and $25 \%$ are strongly disagree. With regard to the managing the social life, $25 \%$ are agree, $19 \%$ are strongly agree and $24 \%$ strongly disagree. Around $24 \%$ of the women employee agree with the participation in family discussions, $20 \%$ are strongly agree and $24 \%$ are strongly disagree. Above analysis indicates that the majority of the women employees agree with the taking care of children than the parents and they are also agree with maintaining family relations, managing the social life and participating in family discussions than the strongly agree.

\section{Self-Management of Women Employees}

Women employees working in banking sector to maintain quality of work can have serious implications personal life of an individuals. This can be occur when the burden, obligations and responsibilities of work and personal life become incomplete, it is very difficult to balance work and personal life. In this connection, there is need to study the self-management of women working in banking sector. The relevant data collected and presented in Table -1.07 .

Table.1.07: Women Employees Opinion towards their Self-Management

\begin{tabular}{|c|l|c|c|c|c|c|}
\hline $\begin{array}{l}\text { S. } \\
\text { No. }\end{array}$ & Factors & SA & A & N & DA & SDA \\
\hline 1 & $\begin{array}{l}\text { Spend time } \\
\text { for self } \\
\text { career } \\
\text { development }\end{array}$ & $\begin{array}{c}29 \\
(12 \%)\end{array}$ & $\begin{array}{c}49 \\
(21 \%)\end{array}$ & $\begin{array}{c}19 \\
(08 \%)\end{array}$ & $\begin{array}{c}66 \\
(28 \%)\end{array}$ & $\begin{array}{c}71 \\
(30 \%)\end{array}$ \\
\hline 2 & $\begin{array}{l}\text { Enough time } \\
\text { to think, }\end{array}$ & $\begin{array}{c}46 \\
(20 \%)\end{array}$ & $\begin{array}{c}47 \\
(20 \%)\end{array}$ & $\begin{array}{c}30 \\
(13 \%)\end{array}$ & $\begin{array}{c}71 \\
(30 \%)\end{array}$ & $\begin{array}{c}40 \\
(17 \%)\end{array}$ \\
\hline
\end{tabular}




\begin{tabular}{|c|l|c|c|c|c|c|}
\hline & $\begin{array}{l}\text { plan for } \\
\text { daily } \\
\text { activities }\end{array}$ & & & & & \\
\hline 3 & $\begin{array}{l}\text { Sufficient } \\
\text { time to take } \\
\text { care of my } \\
\text { self }\end{array}$ & $\begin{array}{c}44 \\
(19 \%)\end{array}$ & $\begin{array}{c}38 \\
(16 \%)\end{array}$ & $\begin{array}{c}(13 \%) \\
(21 \%)\end{array}$ & $\begin{array}{c}73 \\
(31 \%)\end{array}$ \\
\hline 4 & $\begin{array}{l}\text { Sufficient } \\
\text { time to relax } \\
\text { myself }\end{array}$ & $\begin{array}{c}44 \\
(19 \%)\end{array}$ & $\begin{array}{c}56 \\
(24 \%)\end{array}$ & $\begin{array}{c}28 \\
(12 \%)\end{array}$ & $\begin{array}{c}75 \\
(32 \%)\end{array}$ & $\begin{array}{c}31 \\
(13 \%)\end{array}$ \\
\hline 5 & $\begin{array}{l}\text { Undergo } \\
\text { physical } \\
\text { exercise } \\
\text { regularly }\end{array}$ & $\begin{array}{c}38 \\
(16 \%)\end{array}$ & $\begin{array}{c}78 \\
(33 \%)\end{array}$ & $\begin{array}{c}31 \\
(13 \%)\end{array}$ & $\begin{array}{c}54 \\
(23 \%)\end{array}$ & $\begin{array}{c}32 \\
(14 \%)\end{array}$ \\
\hline
\end{tabular}

Source: Primary data.

\section{CONCLUSION}

Above data reveals that the 305 of the women employees are strongly disagree with spend time for self development, $28 \%$ are disagree and only $12 \%$ are strongly agree. Around $30 \%$ of the women employees are disagree with the factor of enough time to think, plan for daily activities, $20 \%$ are strongly agree. With regard to sufficient time to take care of herself, $31 \%$ of the women employees are strongly disagree, $21 \%$ are disagree and only $19 \%$ are strongly agree. Around $32 \%$ of the women employees are disagree with sufficient time to relax herself and $24 \%$ are agree with this. With regard to undergo physical exercise regular, $33 \%$ are agree and $23 \%$ are disagree with this. Therefore, it can be concluded that the majority of the women employees are working in banks are not have sufficient time for their career development, take care of herself.

\section{REFERENCES}

[1] Atkinson, J., and N. Meager. (1986) "Changing working patterns: How companies achieve flexibility to meet new needs". London: Institute of Manpower Studies; National Economic Development Office.

[2] Bhagwagar, H. (2009) "Need for workplace counseling in India".

Http://prod.bolohealth.com/healthzones/21-totalhealth/article/165-needfor-workplace-counseling-inindia.

[3] Bharat, B. (2008) "Longer working hours for computer software engineers", India.

Http://www.saching.com/Article/Longer-workinghours-for-

Computer-Software-EngineersIndia/1088

[4] Elizabeth W., Calvin W., \& Janice R (2008). "Women and work-life balance: is homebased business ownership the solution?”, Equal Opportunities International, 27 (3), 258-275.
[5] Farid A. Muna \& Ned Mansour, (2009). Balancing work and personal life: the leader as acrobat. Journal of Management Development, 28(2), 121-133.

[6] Galinsky, Ellen \& Bond, James T. (1998). The 1998 Business Work-Life Study: A Sourcebook Executive Summary. New York: Families and Work Institute, http://familiesandwork.org/summary/worklife.pdf

[7] Jarrod M. Haar (2007). "Exploring the benefits and use of flexitime: similarities and differences", Qualitative Research in Accounting \& Management, 4 (1), 69-82.

[8] Kossek, E. E., \& Nichol, V. (1992). The effects of an on-site childcare on employee attitudes and performance. Personnel Psychology, 45, 485-509.

[9] Lewis, S., Watts, A., \& Camp, C. (1996). Midland Bank's experience, In S. Lewis and J. Lewis (Eds.) The Work-Family Challenge. Rethinking Employment. London: Sage.

[10] Perry-Smith, J. E. \& Blum, T. C. (2000). RESEARCH NOTES - Work-Family Human Resource Bundles and Perceived Organizational Performance. Academy of Management Journal, 43(6), 11.

[11] Ramachandra Aryasri, A., \& Suman Babu, S. (2007). Work-Life Balance- A holistic Approach.Siddhant-A Journal of Decision Making, 7 (1), 1-11.

[12] Raabe, P.H. (1990), "The organizational effects of workplace family policies", Journal of Family Issues, 11, 477-486.

[13] Sindhu \& Suman Babu, S. (2008). Achieving WorkLife Balance-Women Perspective. Indian Journal of Training and Development, 38(1), 79-86.

[14] Watson Wyatt Worldwide., "Human Capital Index: Human capital as a leader of shareholder value, 2001/2002 Survey Report", 2002, Watson Wyatt Worldwide: Washington. DC. www.watsonwyatt.com

[15] Arthur, M. \& Cook, A. (2004), "Taking stock of work-family initiatives: How announcements of "family friendly" human resource decisions affect shareholder value", Industrial Relations Review, 57 (4), 599-613.

[16] Amato, P. R., D. R. Johnson, A. Booth, and S. J. Rogers. (2003) "Continuity and change in marital quality between 1980 and 2000", Journal of Marriage and Family 65 (1): 1-11. 